\title{
EARLY DAYS OF THE NOVEL CORONAVIRUS: PUBLIC RESPONSE IN SOCIAL MEDIA DURING THE FIRST MONTH OF THE OUTBREAK
}

\author{
Maris Kuperjanov \\ Archivist-referent, Department of Folkloristics \\ Estonian Literary Museum, Estonia \\ maris.kuperjanov@folklore.ee
}

\begin{abstract}
The aim of the article is to give an overview of the first month of the novel coronavirus outbreak and of the public reactions to the news in media comments and social media environments in both local Estonian and global contexts. The pandemic was still ongoing at the time the article was published and, with some modifications and new emphases, vernacular reactions in the media (incl. social media) continued flourishing. During the first month (January 2020), the growing flow of information and rapid escalation of the situation made the topic more noticeable in both the media and social media, and thus provided a fertile basis for jokes and internet memes, legends, fake news, misinformation, conspiracy theories, etc., as was the case with the former bigger epidemics and pandemics. As it has also been observed previously, the consequences of some fake news, misinformation, and conspiracy theories may often be more harmful for society than the disease itself. Several motifs and storylines are universal and surge as similar situations arise both in Estonia and all over the world.

The article also presents a selection of more prominent topics and examples of the outbreak from social media environments during the initial phase of international awareness of the novel coronavirus.
\end{abstract}

Keywords: conspiracy theories, coronavirus, internet memes, public health, social media

This article is an empirical approach to initial rapid reactions aroused in response to the emergence of an unknown viral outbreak in China, the identification of a novel virus not yet described in humans, and a fast response to constantly changing news in social media. I followed the news published in several international media channels (BBC News, Channel 4 News, Deutsche Welle, Global News, Arirang, etc.) during the first month of the outbreak (January 2020), but soon the news from China reached also local Estonian media 
(e.g., Postimees, Delfi, Eesti Ekspress) and the topic became more visible domestically. To assess more objectively what was happening in the media and social media, I observed disease outbreak news reports and subsequent daily situation reports issued by the World Health Organization, as well as the first information and articles in medical journals The Lancet and JAMA. To gather the emerging virus-related material for the research archive of the Department of Folkloristics (EFITA) of the Estonian Literary Museum, I also relied on my friends and colleagues who forwarded to me the thematic material they encountered, mostly memes, jokes, and stories. Therefore, the material (consisting of approximately 130 images and 800 text examples) was not collected specifically by keyword search but was a random sample that reflected the general distribution of opinions, reactions, and memes. Already during the first month of the international knowledge of the outbreak, the emergence and, in some cases due to the time-critical nature of the material, also the disappearance of more popular themes can be noticed.

Internet studies, including the study of internet medicine and memes, have been popular in the last decades (e.g., Blank 2009; Goldstein 2004; Shifman 2014; Kõiva 2010, 2014; Voolaid 2014; etc.), yet these have mainly addressed other types of diseases or cases; however, epidemic lore has an important role also in internet folklore (e.g., HIV, SARS and Ebola lore). Having evolved from the first identified cases to a global pandemic in barely a few months, the novel coronavirus outbreak gave an opportunity to observe in real time the emotions and reactions accompanying the first information bits about the new virus and the rapid changes that occurred simultaneously all over the world.

In order to understand the material, it is useful to recall the timeline of the first month of the outbreak. On 31 December 2019, the World Health Organization (WHO) China Country Office was informed of cases of pneumonia of unknown etiology detected in Wuhan City, Hubei Province of China. The outbreak was associated with exposures at a seafood market in Wuhan, which was closed down for environmental sanitation and disinfection on 1 January 2020. As of 3 January 2020, a total of 44 patients with pneumonia of unknown etiology were reported to the WHO by the national authorities of China (WHO 2020a). The Chinese medical authorities identified a new type of coronavirus (2019-nCoV, on 11 February 2020, officially named virus SARS-CoV-2, causing disease COVID-19), which was isolated on 7 January 2020. Other respiratory pathogens such as influenza, avian influenza, adenovirus, SARS-CoV, and MERS-CoV were ruled out as the cause (WHO 2020b). Coronaviruses (CoV) are a large family of viruses that cause diseases in mammals and birds; six of them were previously described as affecting humans, causing illnesses ranging from the common cold to more severe diseases such as SARS (outbreak in 2002-2003 
resulted in 8,098 cases, including 774 deaths reported in 17 countries) and MERS (first reported in Saudi-Arabia in 2012, with the known case fatality rate of ca 34 percent). The novel coronavirus is a new strain that has not been previously identified in humans; the suspected route of transmission at the beginning of the outbreak was from bats to snakes or pangolins and then to humans. The origin of the virus is under investigation to date.

The genetic sequence of the 2019-nCOV China shared with other countries on 12 January 2020 enabled the rapid development of specific RT-PCR diagnostic tests. According to the information passed on to the WHO by Chinese authorities on 11 and 12 January, 41 cases with the novel coronavirus infection were preliminarily diagnosed in Wuhan, seven of them severely ill, and also the first death of a patient with other underlying health conditions was reported. According to the official data from China, made available to the WHO on 12 January 2020, no additional cases had been detected since 3 January 2020. At this stage, there was no infection among healthcare workers and no clear evidence of human-to-human transmission reported by Chinese health officials (WHO 2020b). However, on the same day, doctor Dr Li Wenliang was diagnosed with $\mathrm{nCoV}$, so the human-to-human transmission was obvious. He was the first to warn about a possible outbreak of the new virus on 30 December 2019, when he posted a warning to a group of fellow doctors about seven patients with SARSlike symptoms, who had been hospitalized and quarantined in his hospital (see Wenliang). This was deemed as disturbing the social order by local authorities and the doctors were targeted by the police (Xiong \& Gan 2020). Dr Li died of the disease on 7 February 2020, and this provoked additional anger against the Chinese authorities and accusations that if the doctors had not been harassed and their warnings had been taken seriously, the outbreak would have been contained better and faster.

The timing of the outbreak was of the utmost importance regarding the quick spread of the virus - China celebrated the Lunar New Year (from 10 January to 18 February 2020), which can also be considered as the largest annual human migration in the world. It is estimated that people take around three billion trips for the Chinese New Year holidays both in China and abroad.

Soon after the 2019-nCOV specific RT-PCR tests were available, the first labconfirmed $\mathrm{nCoV}$ case abroad was reported in Thailand on 13 January 2020. The case was clearly imported from Wuhan, China: the patient developed symptoms on 5 January and travelled to Thailand on 8 January. The first cases in Japan (15 January) and South Korea (20 January) followed shortly, also originating from Wuhan, China. The first case in America was reported on 23 January and in Europe and Australia on 25 January 2020. 
The Chinese authorities decided to quarantine Wuhan and several other cities in Hubei Province on 23 January 2020 to prevent the further spread of the virus. Still, it is estimated that around five million people from Wuhan travelled out of the city before the closure and therefore the increase of infected patients was expected. However, these draconian measures implemented by the Chinese authorities possibly helped to delay serious outbreaks in other countries, providing at least some opportunity for preparedness.

Medical journals (The Lancet, JAMA, etc.) began to publish virus-related rapidly changing and evolving information and articles, creating designated novel coronavirus-related resource centres, ${ }^{1}$ where it was possible to follow topical evidence-based information. The WHO also compiled a virus-related emergency page (WHO 2020c), where it was possible to get advice about the virus and protection against it, and to follow daily situation reports. The Johns Hopkins University started tracking official cases according to the Centers for Disease Control and Prevention (CDC) and WHO data from all over the world on 20 January 2020 , showing the concentration and spread of the virus, and the topic was also included on other world statistics websites (e.g., Worldometer, Our World in Data). The WHO Emergency Committee held meetings about the virus outbreak, but it was not considered serious enough to declare public health emergency of international concern before the meeting on 30 January 2020 (WHO 2020d). The officially announced confirmed infections on a global level at the time were 7,736 in China (including 170 reported deaths) and 82 infected persons in 18 other countries. According to the WHO, the aim of declaring emergency was not the situation in China, but the possibility that the virus outbreak would be a very serious problem when it reaches poorer countries with weaker health systems.

\section{INCREASE IN INFORMATION FLOW IN (SOCIAL) MEDIA AND PUBLIC REACTIONS}

The increasing information flow from China and other affected countries in January made the topic of the virus outbreak more noticeable in both traditional and social media. The number of articles, posts, videos, as well as comments and reactions to them grew significantly. Similar to former bigger epidemics and pandemics, this provided a fertile basis for jokes and internet memes, legends and conspiracy theories, etc.

Memes differ from iconic images and viral texts that do not experience much alteration (Denisova 2019: 8). Both modified memes and more static elements, such as viral texts, slogans, and images related to the topic, emerged after virus 
notifications. The wide variety of meme generators makes it easy to quickly produce, use previous prototypes, copy, alter, and share the created content in social media. Many well-known and often-used memes were modified to match the content of a specific event or reflect topical news (e.g., Joey's Delayed Reaction, That Would Be Great, The Plague Doctor, to name a few from Know Your Meme site, ${ }^{2}$ which researches and documents internet memes and viral phenomena), but there were also more specific ones to reflect this particular event. When humour travels across borders, nations, and cultures, it acquires new interpretations through translation, but also through adjusting to the target culture, at the same time retaining its connection to the source (Laineste \& Voolaid 2016: 28). In addition to the material in English, I kept track of local Estonian memes and media responses. Most of the content in the local language, at least at this initial stage of the epidemic, was mainly translated and perhaps somewhat customized, as an example of user-generated globalization (Shifman \& Levy \& Thelwall 2014: 728). The relative insignificance of local references may be attributed to the fact that at that time the topic was not yet highly relevant in the country as there were no direct contacts with the outbreak, no infected persons (the first case was diagnosed in Estonia on 26 February 2020), no direct transport routes to Wuhan or China, etc., which would have been some possible reasons to provide a local aspect to the globally spreading memes.

\section{Coronavirus is transmitted through human contact.}

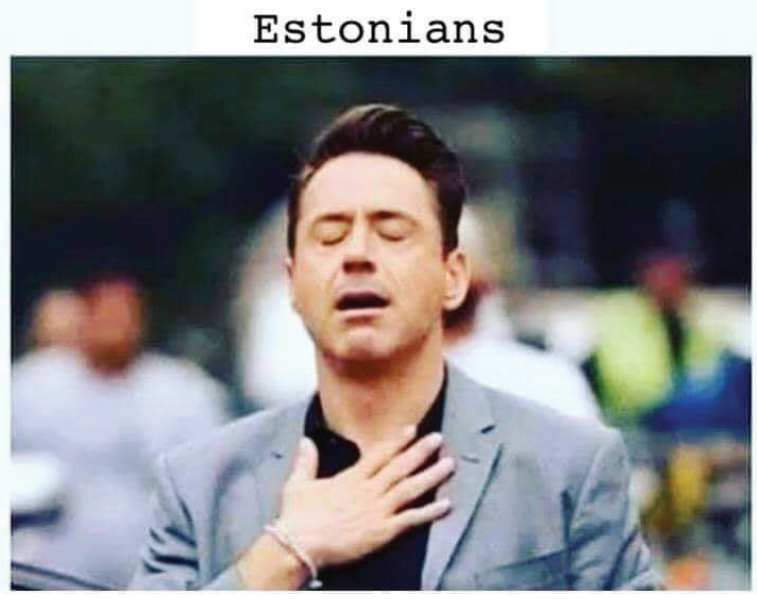

Figure 1. Estonians (as well as Finns and other Nordic nations, but also introverts, programmers, etc.) are relieved as social distancing is habitual anyway (EFITA F32-002-0112). 
The information and knowledge of the topic was changing rapidly, and new information became available on a daily basis, creating a mixture of most recent, adjusted, and already outdated news; also, mis- and disinformation was highly visible. Misinformation can emerge in various forms and ways and can be shared with different intentions or a mixture of intentions, for example as rumour, mistake, or humour, whereas disinformation is deliberately misleading, consciously constructed, and malicious. To distinguish between real news and fake news or rumours is often difficult for people even in normal circumstances; this kind of rapidly changing situation makes it harder for the recipients to analyse the information and differentiate real stories from fake ones. As Lynne S. McNeill has pointed out, the stories do not always circulate as news articles, but rather as legends (McNeill 2018: 494). A new virus outbreak is not different from other significant events: the society often responds to such outbreaks by constructing rumours, legends, jokes, and conspiracy theories. A comparison of the plague legends from the late Middle Ages and past-century AIDS-related urban tales and their background demonstrates that there are striking similarities in terms of both specific behavioural patterns and oral tradition (Hiiemäe 1999). However, unlike in the times of historical epidemics, the spread of epidemic lore and public reactions has become instantaneous and global due to the possibilities of the Internet. American folklorist Jon D. Lee has examined responses to epidemics in the case of the previous coronavirus SARS, showing similarities between the narratives of SARS and of previous HIV/AIDS and H1N1 influenza, and suggests that disease narratives are constantly recycled (for more on the recycling of epidemic lore see Hiiemäe et al. 2021). He also points out the often more damaging effect of the narratives than that of the disease they reference (Lee 2014). Julii Brainard and Paul R. Hunter have also indicated the harmful role of misinformation related to infectious disease outbreaks, and show the impact of influenza, monkeypox, and norovirus (Brainard \& Hunter 2019).

Conspiracy theories usually tend to circulate and be eagerly discussed in echo chambers, in which people with similar world views, interests, and beliefs participate, yet special events enable the topics to surge and be more visible in the mainstream media and social media platforms. After such surges the theories often continue to live their own life on designated websites and channels in latency, as can be observed for popular topics like Freemasons, clandestine government plans, New World Order, etc., and emerge again when the conditions are favourable. The main aims seem to be a search for the enemy or culprit, disbelief in natural phenomena or processes, and sharing of the "special knowledge" that the masses who believe in the official information do not possess. According to American politologist Michael Barkun's classification, in 
the case of a novel coronavirus, both event conspiracy and systemic conspiracy seem to surge, the theories mostly offering multiple options to believe (and share) different versions of the origin of the virus. It is possible to observe that posts refer to previous significant events not connected to the case, sometimes deliberately changed to match the current situation. Although some conspiracy theories may have certain benefits, raising issues in society that need to be addressed, these have been predominantly linked to harmful social, health, and political consequences (Douglas et al. 2019: 17).

Xenophobic responses accompanied the infectious disease threats in the past and the current pandemic followed this pattern (cf. White 2020; Shimizu 2020). Some signs of racism started to emerge as the virus progressed; there were some news describing the avoidance experienced by Chinese journalists, and later on also by the entrepreneurs in Chinatowns in various countries. In the spreading memes and comments it can be observed as a reference to Asian food (bat soup), recommendations to avoid coughing and sneezing Chinese students, in some conspiracy-related comments (virus was man-made and/ or designed to affect only Asians/Chinese, therefore no threat to other races or nations), etc. In response to the avoidance suggestions, some Asian people shared photographs of themselves with the sign 'I am not a virus'. Still I would estimate that the racism issue was not predominantly intended to incite tensions between different races and make the containment harder during the early phase of the outbreak - differently from the situation that could be observed during the 2014 Ebola outbreak, when a "white people" conspiracy hoax spread on Nigerian websites, claiming that the virus had been deliberately created by the Western countries, often by using black magic, evolving to the presumption that Europeans and Americans had a new racist cult that hated Africans and worshipped Ebola-chan, a white lady wearing the uniform of a nurse, who is holding a bloody skull, her long and dangling hair looking like a dangerous Ebola virus strain (Kharel 2014). In the case of Ebola, the hoax added more fear and tension to the already complicated situation in which the healthcare workers trying to contain the outbreak were threatened and attacked by people who believed the disease was only fictional, spread by medical personnel, or that the purpose was harvesting their organs for sale in Europe. The fear and violence towards medical workers may in severe cases even lead to fatalities; for example, in the Democratic Republic of Congo four health workers were killed just shortly before the timeframe observed in this article, in November 2019 (Burke 2019). The meme of the personified virus, Ebola-chan, acted also like a sort of chain letter, threatening with excruciating pain and death unless the viewer posted the phrase "I love you Ebola-chan" in the comment section; the same principle has been used for other virus outbreaks, e.g., Zika, and also in this case as Corona-chan or Wuhan-chan. 
Below is a brief overview of some more prominent topics and examples from social media environments about the outbreak from January 2020, the first month of the international awareness of the novel coronavirus.

\section{THE CURSE OF THE TWENTIES}

As the first information of the new virus became publicly available at the beginning of 2020, there were many comparisons between the previous and current year ("2019 the year was bad yeah, but 2020 is like 2019 but worse in a single month"3 (EFITA F32-001-0014)), New Year's resolutions ("New year's resolution: Survive 2020!" (EFITA F32-001-0155)), and the highlighting of some major global events of January 2020 ("First month of the new decade we've unlocked these achievements: China: coronavirus; The US and Iran: nearly World War III; Australia: bushfires; Kobe: dies; The Philippines: volcano" (EFITA F32-0010011)). We can also see a number of suggestions to restart 2020 or go back to year 2019 to keep bad things from happening ("This is why we should of make a continue of 2019 by 2019 version 2 . If it was 2019 version 2 , nothing would be bad" (EFITA F32-001-0012)).

Many people shared references to some previous major disease outbreaks which had occurred in the twenties of different centuries - in every hundred years there seems to have been a large pandemic that followed the same pattern as the current viral epidemic in China (1720 - the Great Plague of Marseille, 1820 - cholera pandemic, 1920 - the Spanish flu). Some of these comments and memes were just of a describing nature, but others also mingled with conspiracy theories, mainly indicating that this could not have been a coincidence, something evil had to be going on. This category was one of the earliest in my material and although this time-sensitive topic was highly visible at the beginning of January 2020, its importance diminished fairly quickly by the end of the month.

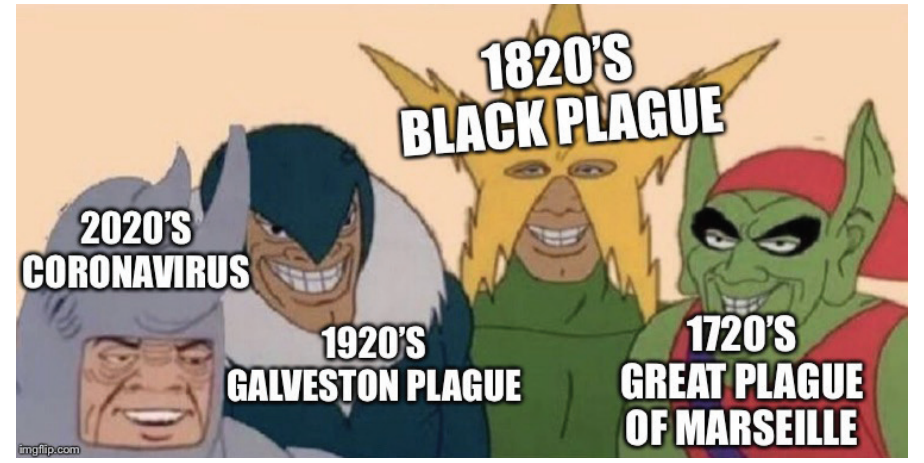

Figure 2. An internet meme depicting major disease outbreaks in the twenties of different centuries (EFITA F32002-0082). 


\section{CORONA NAME-RELATED MEMES}

One of the largest groups is the Mexican Corona beer brand related news, memes, and comments provoked by the name of the virus family. The topics vary from Corona beer as a virus spreader, vaccine, and treatment to Corona beer company allegedly suing the Chinese government due to "putting the bad taste in people's mouths regarding the name Corona“. ${ }^{4}$ Different memes of Corona beer circulate in the web with various added virus-related texts. As Corona advertisements often feature lime as an addition to beer, it has also provoked the connection with Lyme disease.

It has been noted that Google searches of the viruses/diseases are peaking at the time of the outbreaks, as was described in the case of Ebola in 2014 and now for the novel coronavirus; however, at this time it was pointed out that searches for corona beer virus, beer virus and beer coronavirus increased significantly after the number of virus outbreak news increased. From 18 to 26 January, the number of enquiries for corona beer virus increased by 2,300 percent (Bostock 2020).

The name-related group is also one of the largest to provoke the earliest local lore besides internationally spreading memes, as in addition to internationally known 'corona' meanings koroona (or novuss in Latvian) is a well-known game originating from Estonia and Latvia. Although the name topic has been represented continuously, the main phase of the development, spread, and significance of this group remained at the beginning of the outbreak.

Figure 3. This meme uses both Corona beer and koroona game: Coronavirus - now also in P.E. classes of Estonian schools (EFITA F32-0030002).
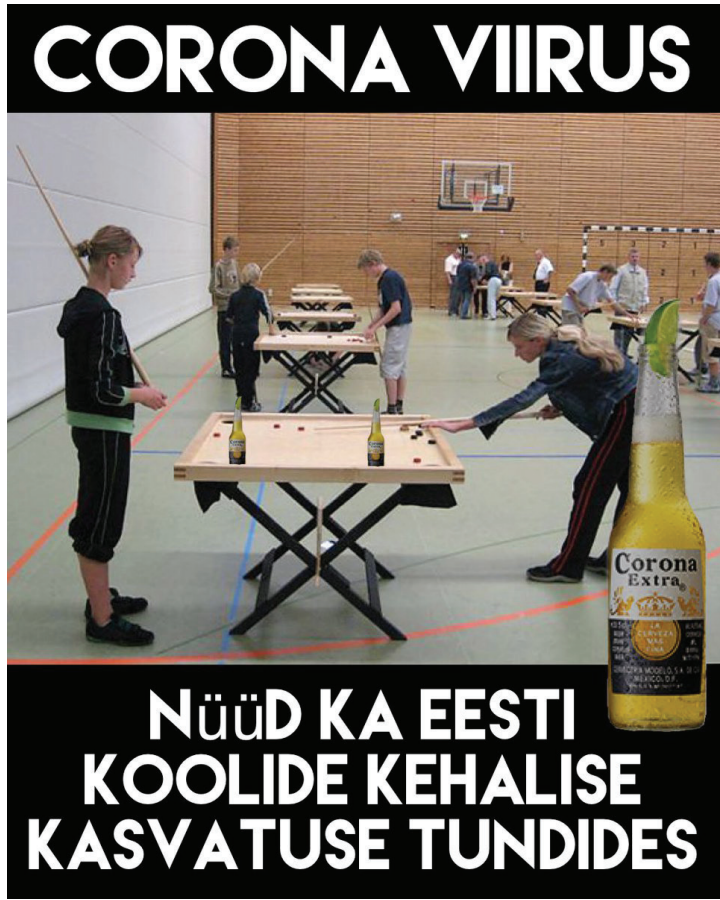


\section{BAT SOUP, MADE IN CHINA, KUNG FLU}

From the very beginning of the outbreak, people speculated online about the origin of the virus. The ground zero for the outbreak was believed to be a seafood market in Wuhan, which traded illegal wildlife among other goods. This prompted many remarks about Chinese cuisine and eating habits. One of the most viral videos showed a Chinese woman allegedly eating bat and admitting it tasted like chicken; it caused outrage in social media, and the Chinese eating habits were blamed for the outbreak of viral diseases. Actually, the video was filmed in an archipelago in the western Pacific Ocean in 2016, and had no connection whatsoever to the Wuhan market or disease outbreak; yet it is evident that every little thing can be a powerful catalyst in social media flame.

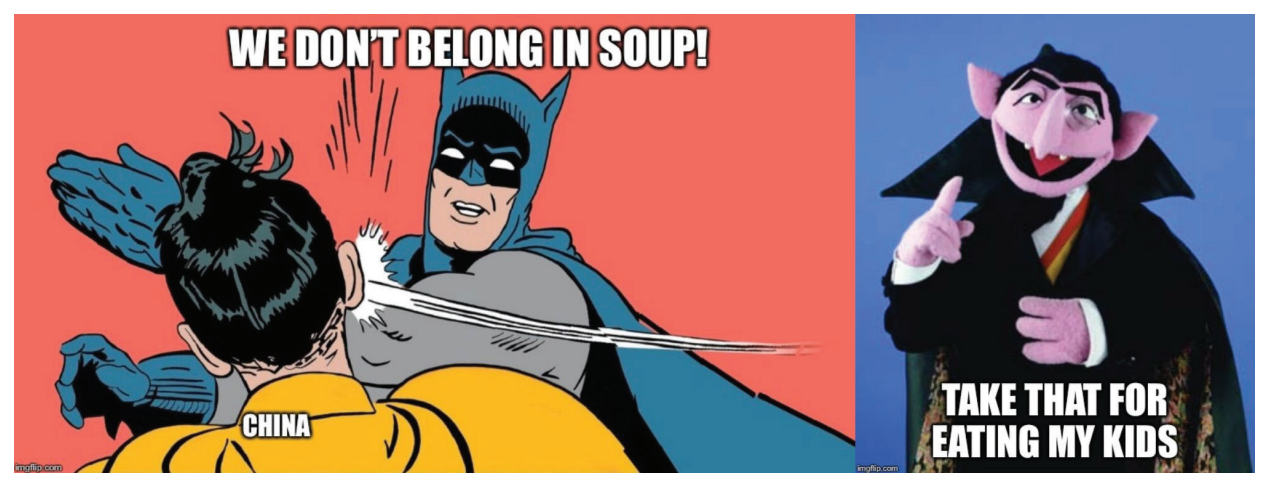

Figure 4. Bat-related memes (imgflip.com, author's collage).

Other memes indicate that there is no need to worry about the rest of the world - the virus will not last long because it is "Made in China"; sometimes it also resulted in a recognition that everything is produced in and comes from China in the contemporary globalized world.

Don't worry about Coronavirus bcoz its MADE IN CHINA (EFITA F32001-0045).

Wait isn't EVERYTHING in our daily lives MADE FROM CHINA (EFITA F32-001-0046).

As at the beginning of the outbreak the spreading speed and mechanisms of the virus seemed to be similar to those of influenza, the Kung Flu (originally in slang meaning flu originating from Asia but now used also for the novel coronavirus) 

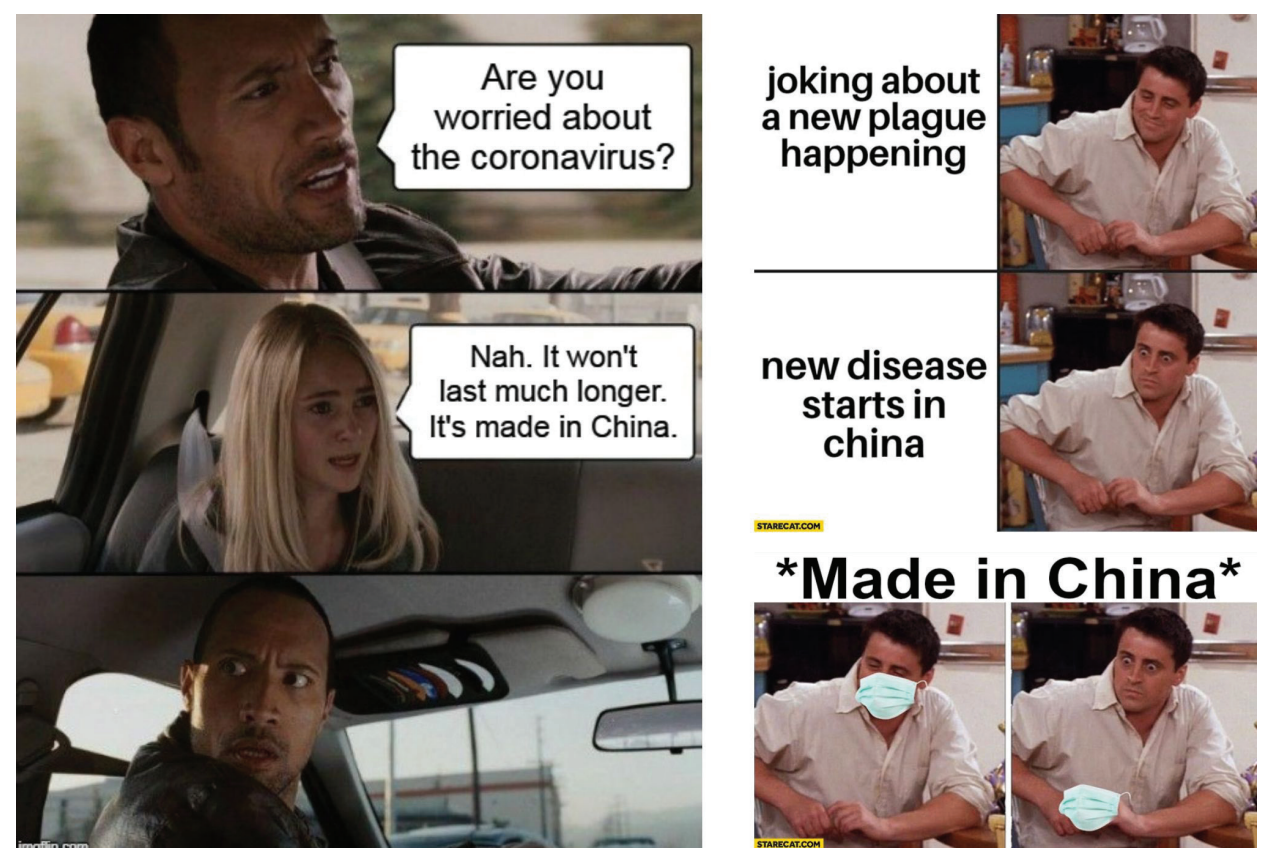

Figure 5. Memes depicting the "Made in China" comments (imgflip.com, starecat.com, author's collage).

memes were associated with it as a virus name and also in the meaning of the martial art to fight the virus; for example, a meme of a doctor reassuring that there is nothing to be worried about as he knows Kung Flu. The virus has also been called Wuhan Flu or WuFlu, or the $\mathrm{CCP}^{5}$ virus as a hint to the political regime in China. The significance of new China-related topics decreased as the virus spread all over the world, yet they can still be found.

\section{REFERENCES TO THE WORLD OF ENTERTAINMENT}

As expected with the disease outbreaks, there are myriads of posts and comments related to the contemporary entertainment world, mainly apocalyptic computer and video games, movies, and TV shows, the Plague Inc. computer game being the most relevant in this case. Questions are asked about who is playing the game that has now been transferred into real life ("When God decided to play Plague inc." (EFITA F32-001-0017)), game strategies are suggested to deal with the virus destruction/containment or to flee from it to a safe 
place, for instance, to move to Greenland ("Plague inc players be like: MOVE TO GREENLAND! Me, an intellectual: Go do that, wait till it evolves cold resistance" (EFITA F32-001-0020)).

References to movies with epidemiologic content indicate similarities with the current situation, some of them insisting that they predicted the coronavirus. The most prominent would be the animated comedy "The Simpsons", which has been credited for years by its fandom for several accurate predictions, the more widely known examples being predictions of Donald Trump becoming the US president, the discovery of the Higgs boson, the invention of autocorrect, smartwatches, etc. Other more frequently mentioned films under this topic are the American thriller "Contagion" (2011), the TV series "Pandemic" (2007), and later on the Netflix docuseries "Pandemic: How to Prevent an Outbreak", released right at the beginning of the outbreak in January 2020, as well as South Korean action films "The Flu" (2013) and "Train to Busan" (2016), the latter with the recommendation of a possible new sequel called "Planes from Wuhan".

Popular art memes have also found their place in the virus responses around the world, Estonia being no exception (e.g., "The Last Supper", "The Birth of Venus"). The occurrence of the topic has remained quite stable in time; the scenes or characters of the entertainment world are omnipresent in memes in general as well as in the current virus lore and evolve as the crisis progresses.

\section{SATIRICAL ILLUSTRATIONS IN NEWSPAPERS WORLDWIDE}

As the virus spread, it became more and more topical for the press worldwide. In addition to informational articles, it has initiated thematic illustrations to this day, and these can also become viral. One of the scandalous illustrations depicting a Chinese flag with its five yellow stars, replaced with images of coronaviruses, was printed in the Danish newspaper Jyllands-Posten on 27 January 2020. The same newspaper had a previous scandal with printing the Muhammad cartoons in 2005, which even escalated into violence (see Muhammad cartoons controversy). On this occasion the feedback was fortunately not that severe, but still resulted in furore in both the political sphere and in social media.

The Chinese embassy saw the image as an insult to China, hurting the feelings of the Chinese people, and demanded a public apology from the Danish newspaper and the illustrator personally. In response the newspaper declared that in the circumstances where the virus had already claimed the lives of over 100 people, they had no intention of degrading or taunting, and the drawing was supposed to do neither; it could have been the case of two different cultural understandings (The Local 2020). 


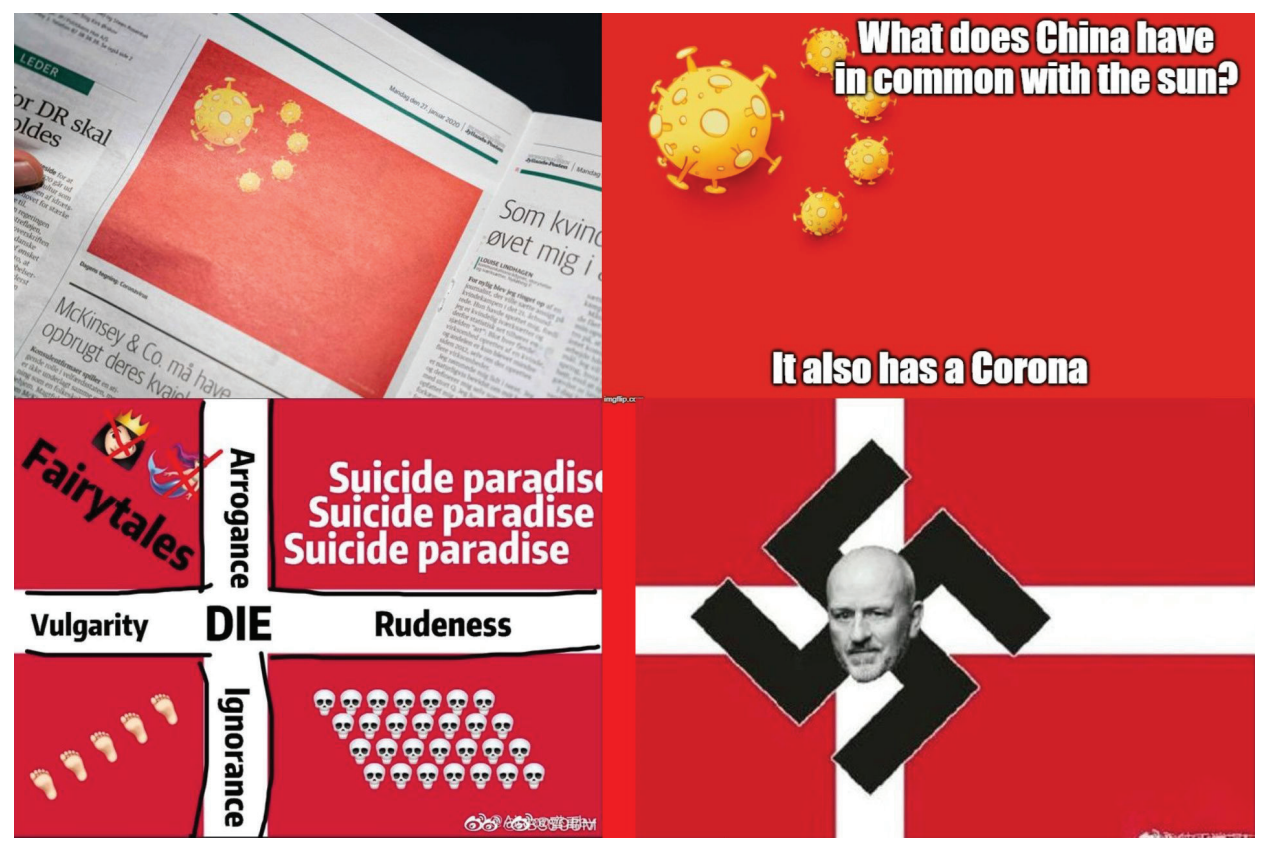

Figure 6. Original illustration from Jyllands-Posten and the responses from imgflip.com, Twitter, and Weibo (author's collage).

\section{COMPARISON WITH OTHER KNOWN VIRUSES AND DISEASES}

In the initial phase of the outbreak, the novel coronavirus was estimated to be far less deadly than other severe coronaviruses, SARS and MERS, yet as infectious as seasonal influenza. Many comments referred to annual fatalities due to seasonal flu, cancer, or heart diseases, indicating that the current virus was not serious and panic had been instigated by the media to create hype and gain from it like with previous virus epidemics.

Imagine if no one watched news. This would be exactly what it is... nothing. (EFITA F32-001-0076)

hmm its nothing compared to the flu. (EFITA F32-001-0077)

The arrogance was quite common in these circumstances, reassuring people that there was nothing to worry about, the virus would not affect white people, or only old and weak people die. As it was a new virus with no specific cure, no vaccine, no previously acquired antibodies, and there were not enough possibilities to treat the growing numbers of severe cases due to the overloaded 
medical system, the situation was indeed serious in Wuhan by the end of the first month of the outbreak. At that time, it was too early to estimate $R_{0}$ (the basic reproduction number showing how contagious the infectious disease is), the percentage of mild and severe cases requiring the intensive care unit (ICU), as well as the case fatality rate (CFR), and the way the outbreak could affect the rest of the world. The comparison with the flu and downplaying of the virus consequences also continued later, and in several countries the leading politicians also played their part in it (e.g., the USA, Brazil, etc.), and this provoked responses in social media.

\section{ORIGINS OF THE VIRUS AND VARIOUS CONSPIRACY THEORIES}

Like any other major event, the sudden outbreak of the novel virus provided plenty of opportunity to interpret the news in various ways and discuss the origins of the virus. The beginning of January seemed quite quiet at least in the mainstream media; the topics started to emerge as the information flow regarding the infection gradually grew in the second and third decade of January. The Chinese' official statement that the virus started to spread in a seafood market was often objected and by the end of the month these theories evolved into numerous different narratives; some of them were refuted shortly after emerging and are not in active circulation anymore, whereas others are still spreading around the world.

One of the first theories was that Chinese agents working in a Canadian laboratory were caught smuggling the virus to China and then it was weaponized. Canada soon denied the probability of theft. In some cases, other countries have also been held responsible for the outbreak, mainly the USA.

Many articles and videos suggest that the virus escaped from China's only P4/BSL-4 laboratory, which handles level 4 biosafety pathogens that are most dangerous, with a high mortality rate and no known treatment, such as Ebola, SARS, etc. It is hinted that China was developing bioweapons in the laboratory and the current novel coronavirus is a new bioweapon designed by the Chinese government. The biosafety laboratory in Wuhan indeed studies hazardous viruses and as in 2017 US biosafety experts had expressed concerns that viruses could 'escape' from the laboratory due to unpredictability of laboratory animals, it has now been speculated that the laboratory is the source of the spreading virus. Soon pictures appeared of the alleged logo of the Wuhan biotechnology laboratory, which was oddly similar to that of the Umbrella Corporation (reference to Resident Evil video games / film series where the Umbrella Corporation 
was responsible for the outbreak and the Raccoon City was destroyed). Later it was revealed that the laboratory with a similar logo was located in Shanghai and was not related to the Wuhan laboratory.

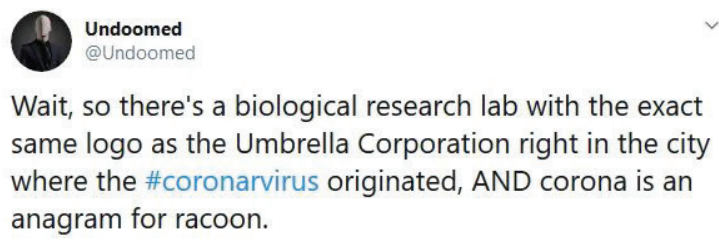

What the fuck has this timeline been smoking???

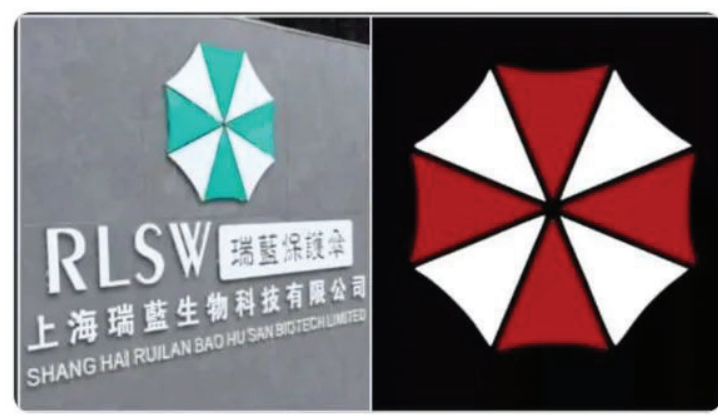

1:27 PM · Jan 26, 2020 - Twitter Web App

26.2K Retweets $\quad 64.6 \mathrm{~K}$ Likes

Figure 7. A Twitter post from user Undoomed has been circling the news and comments as an example of the similarity of the logos of the Chinese research laboratory and the Umbrella Corporation. Source: https: / / twitter.com / undoomed/status / 1221545217641402370 , last accessed on 4 February 2021.

There were also rumours and beliefs that pharmaceutical corporations were responsible for distributing the virus in order to earn fortunes by first provoking panic and then selling the vaccines and remedies. In many cases there were suggestions that the vaccines/cure had already been developed before the virus was released; this was also a common theory with previous outbreaks. The denial of the modern science-based world view was common; some commentators indicated that the current knowledge of viruses, the zoonotic nature or mutation ability of viruses was false. It was argued that the transfer of the virus from 
animal to human could not have been possible as eating habits regarding wildlife had been similar for centuries and so the transfer should have happened long ago - which brought us back to the man-made virus theory.

seems to be about a $1.22 \%$ death rate. So much coverage, must be for making people run to get the soon to appear vaccine. (EFITA F32-001-0061)

Corona virus is a patented disease which means there's also a patented cure. Look it up. (EFITA F32-001-0062)

One of the recurring conspiracy themes is related to Event 201, a high-level pandemic exercise held only a few months before the virus outbreak, on 18 October 2019. The event was hosted by the Johns Hopkins Center for Health Security in partnership with the World Economic Forum and the Bill and Melinda Gates Foundation. The purpose was to point out areas where public/ private partnerships would be necessary in response to a severe pandemic in order to diminish large-scale economic and societal consequences (Event 201). The script of the exercise simulated an outbreak of a new coronavirus that would kill 65 million people in the first 18 months. Many people back then disapproved that the focus of the exercise was not the health and well-being of people but the economic consequences for governments and private corporations. The conspiracy theories regarding the event were expected when shortly after the pandemic exercise a real epidemy of a novel coronavirus occurred; it was suggested that the exercise was a prediction, or hinted that this could not have been a coincidence.

Public health simulations with epidemic scenarios are conducted consistently at various levels; in addition to scientific, economic or political aspects these may rely on popular memory, historical research, and systematic use of public health records (Keck \& Lachenal 2019: 28). Another role-playing exercise connected with another billionaire, George Soros, is also mentioned; it was called Food Chain Reaction: A Global Food Security Game ${ }^{6}$ (2015) and predicted that in five years' time the population growth, rapid urbanization, extreme weather conditions, and political crises (and as commentators stress: disease! 2020!) combine to threaten global food security. It was being questioned if these scripts of the simulations were now coming to life and who was behind it, yet the severe economic and societal issues of a possible pandemic brought up by these exercises were not yet noticeable for the Western general public during this initial phase and therefore rarely appeared in the material collected at the time.

As for years Bill Gates has warned the society that the greatest risk of a global catastrophe nowadays could be a highly infectious virus and the world has no strategies to stop or fight the pandemic effectively, he is incorporated 
in the comments both as an individual and as a representative of the Bill and Melinda Gates Foundation. He is also visible in connection with another conspiracy topic - depopulation of the planet, according to which the virus was designed and deliberately spread to control the population.

This is one of the ways they're trying to control their population. (EFITA F32-001-0057)

NWO needs $80 \%$ + of all population in each economic zone to be depopulated. This will help. (EFITA F32-001-0165)

The concept of the elite (aristocracy, nobility, landlords, billionaires) being responsible for diseases or any other miseries has been known for centuries. As an example from the local material, it is possible to find tales in the Estonian Folklore Archives of landlords spreading the plague, cholera, murrain, and other diseases (Hiiemäe 1997: 111-114); in the historical tradition collection of the Estonian Cultural History Archives there are also notifications about evil people at the service of the landlord, spreading the plague, or about another landlord having the cure for the disease and the village was spared (Tavast 2020 [1931]).

In recent years the implementation of the new 5th-generation high-speed telecommunication networks has been a target of various concerns and conspiracies. New technologies have often been adopted with hesitation, and one of the reasons for suspicion in this case could be the same as for a virus: it is possible to see neither the virus nor radio waves, they are not tangible and without knowledge and trust in science it is hard to comprehend them. Although the 5G technology has been declared safe, the conspiracies gained popularity as the novel coronavirus surged, trying to explain the emergence and rapid spread of the virus with $5 \mathrm{G}$ (see also Ahmed et al. 2020). The theories were also mixed with vaccine hesitancy and depopulation theories, claiming that by means of $5 \mathrm{G}$ it is possible to activate heavy metals or alleged microchips in the vaccines, enslave people, and/or the world population growth could be reduced. The conspiracy theories linked to $5 \mathrm{G}$ later led to dozens of real attacks made on telecom masts in several countries.

As it is possible to witness in various crisis situations, several conspiracy theories usually circulating in their own designated echo chambers emerged quickly to gain wider audiences and to evolve according to current circumstances. The dissemination of the theories may serve diverse purposes, from sharing them as humour or "secret knowledge" to the attempt to disrupt the society. The prevalence of conspiracy theories related to the virus was growing daily during the second part of the month under review, and later became one of the most fertile topics. 


\section{CLOSING OF THE BORDERS, EVACUATION STRATEGIES, AND PUBLIC RESPONSE TO RESTRICTIONS}

As the virus escalated, the neighbouring countries started to close the borders with China, and the possible restrictions to international travel came under discussion. Several countries were considering repatriation or evacuation of their citizens from the virus epicentre Wuhan. The idea was publicly criticized because of the fear of spreading the disease both by their compatriots and by the potential evacuees in Wuhan. Though the WHO stressed on several occasions that there was no need for disease prevention measures, such as international travel and trade restrictions, most of the biggest aviation companies stopped their flights to mainland China by the end of January 2020.

Several approaches were adopted by different countries with regard to the returnees. At first the health officials of most countries did not find it necessary to quarantine them; it was maintained that the transmission occurred only when symptoms manifested and therefore it was expected that a routine check for the main symptoms of the virus (fever, cough) on arrival at the homeland airport would be sufficient. This irritated the public; on the one hand people insisted that this would not be sufficient to prevent the spread of the virus and accused the governments of a belated response, and on the other hand the opponents claimed that the outbreak was insignificant and posed no threat but was merely a hoax or panic provoked by the media. However, some countries were already more cautious and were contemplating the need for quarantine.

The first countries to speak about evacuation were the USA and Japan (first special evacuation flights on 28-29 January 2020), and other countries followed quickly. Britain and Germany announced their plans to evacuate their citizens and stated that the returning people were supposed to undergo quarantine after arrival. This brought up a new aspect in the topic. In response to the Twitter tweet by Matt Hancock, the British Secretary of State for Health and Social Care, about the isolation of the returning citizens from Wuhan, in addition to public safety issues the question of the human rights of the returning people kept in quarantine arose (The Guardian 2020). The question of human rights and freedoms became more and more highlighted as restrictions and lockdowns were implemented. Germans were evacuated from Wuhan by the German Air Force (Luftwaffe) and quarantined in a military base in Germersheim, which also provoked indications of World War II and concentration camps, and was therefore called coronacaust or Auschwitz'20.

In some cases the local communities opposed the governments' decisions to transfer the evacuees to their communities (e.g. Australia, where reactions also referred to stigmatized leprosy (Michelmore \& Parish \& O’Connor 2020)). 
The fear of the novel and unknown infection coming to the local community was visible.

Several other countries also evacuated their citizens, but the total number of evacuated people was marginal compared to the departure wave before the lockdown of Wuhan on 23 January 2020, and other Hubei Province cities in the following days. News channels in different countries started to publish interviews with people in quarantine and several vlogs of the people sharing their experiences and everyday life became popular. This way the evacuated people became closer to the audience and were not so anonymous and repelled; mostly benevolent and encouraging comments can be found for these texts and videos.

The public responses to governmental restrictions proliferated later at the same pace as the virus and the attempts to suppress it, and gained great popularity starting from March 2020, when most of the world experienced lockdowns and restrictions for the first time. Numerous new topics developed to describe the new normality, including social distancing, working from home, distance learning, travel restrictions, societal and economic crisis, etc.

\section{CONCLUSIONS}

On 31 December 2019, the World Health Organization was informed of the first cases of pneumonia of unknown etiology, detected in Wuhan City, Hubei Province of China. Soon it became evident that the cause was a novel coronavirus that was spreading rapidly. The first cases were detected earlier in the month, but the doctors discussing the possible new virus were arrested and silenced with the accusations of disturbing social order. Many people believe that as the information was not shared publicly in the first place, it led to a faster escalation of the outbreak and also contributed to a heavy flow of topical folklore and alternative theories. The fast escalation has been pointed out also in the comments and memes, as can be witnessed in the following examples:

I bought elderberry syrup! [3 days later] Do they sell family pack hazmat suits? (EFITA F32-001-0162)

Mainstream media in January: It's more likely to get impaled by a wild unicorn than to die from the coronavirus.

Mainstream media in February: Okay the coronavirus is a bit scary but the flu is far deadlier.

Mainstream media in March: The coronavirus pandemic is very, very bad but nuclear apocalypses are arguably worse.

Mainstream media in April: ... (EFITA F32-001-0161) 
After the official information about the outbreak started to come more regularly from China, the information flow in the Western media grew enormously, especially due to the fast escalation of the virus. Similar to any other outstanding events, including the previous virus outbreaks, there was like an explosion in social media - from numerous articles and news stories published, shared, altered, and commented, or social media content creators taking advantage of the situation by using clickbait, to spreading computer viruses (Paganini 2020) exploiting the growing interest in the topic. The power of social media became more and more eminent as the pandemic progressed. We can see the emergence of a wide variety of jokes and memes, but in addition to the pandemic we can witness an infodemic (a blend of information and epidemic), ${ }^{7}$ a massive spread of both accurate and inaccurate information, fake news and conspiracy theories (both ignorant or malevolent to provoke panic), which can also take a physical form, causing protests and material damage, as well as the countermeasures that social media platforms used to contain them. Several social media platforms have involved fact checkers to review and debunk false claims to limit the spread of fake news and fear; others are demonetizing coronavirus-related content to reduce the producing and spreading of the thematic content. The extent of the rumours and misinformation about the virus was so great already at the beginning of the outbreak that public health scientists from several countries published a statement to strongly condemn conspiracy theories, suggesting that the virus does not have a natural origin, confirming that scientists from several countries have analysed genomes of the causative agent and they overwhelmingly conclude that this coronavirus originated in wildlife (Calisher et al. 2020). The official investigation of the origin of the virus is ongoing to date.

The rapid escalation of the outbreak enabled researchers to observe how the focus of the news and, correspondingly, the public response changed within days from something far and distant to something closer and concerning the whole world either from the medical or economic viewpoint. This article provided a global overview of some of the recurrent topics and their representations in the media (incl. social media) during the first month of the pandemic.

Most of the reviewed categories of the collected primary virus-related folklore material in our archive are quite consistent, equally represented also after the first impact of the outbreak, and constantly evolving as the situation changes. However, it is possible to observe that some topics lost their relevance sooner, even within the first month under review; for instance, the time and place of the virus origin became less evident and less important. At the same time other topics also present in the initial stage gained momentum as the pandemic progressed, often driven by the response of politicians or state regulations. The vernacular narrative and belief impact of the novel virus outbreak is more and 
more visible in various fields. The medical aspects (the spread or containment of the virus in different parts of the world, development of cure/vaccines, whether or not it becomes endemic) and the overall global economic and societal consequences continue to provide rich folklore material for an extended period of time.

\section{ACKNOWLEDGEMENTS}

This article was supported by the European Union through the European Regional Development Fund (Centre of Excellence in Estonian Studies, CEES TK 145) and was written within the framework of the research project "Narrative and belief aspects of folklore studies" (EKM 8-2/20/3).

\section{NOTES}

1 See https://www.thelancet.com/coronavirus, and https://jamanetwork.com/journals/ jama/pages/coronavirus-alert, last accessed on 2 February 2021.

2 See https://knowyourmeme.com/, last accessed on 3 February 2021.

${ }^{3}$ Hereinafter the spelling and grammar in citations remain unchanged.

4 See https://empirenews.net/parent-company-of-corona-beer-sues-china-over-bad-pressduring-their-coronavirus-scare/, last accessed on 26 February 2021.

5 Meaning the Chinese Communist Party.

6 See https://foodchainreaction.org/, last accessed on 4 February 2021.

7 The term was coined already in 2003 in the SARS crisis by journalist and political scientist David Rothkopf in a Washington Post column and has seen renewed usage. The WHO started to use the term for COVID-19 pandemic in March 2020 (see https:// www.merriam-webster.com/words-at-play/words-were-watching-infodemic-meaning, last accessed on 5 February 2021).

\section{ARCHIVAL SOURCES}

EFITA - The scientific archive of the Department of Folkloristics of the Estonian Literary Museum

F32-001, F32-002, F32-003 - collections of epidemic folklore (Maris Kuperjanov)

\section{INTERNET SOURCES}

Muhammad cartoons controversy $=$ Jyllands-Posten Muhammad cartoons controversy . Wikipedia. Available at https://en.wikipedia.org/wiki/Jyllands-Posten_ Muhammad_cartoons_controversy, last accessed on 5 February 2021. 
Wenliang = Li Wenliang. Wikipedia. Available at https://en.wikipedia.org/wiki/Li_ Wenliang, last accessed on 5 February 2021.

WHO 2020a = Pneumonia of Unknown Cause - China. Emergencies Preparedness, Response. World Health Organization (website), 5 January. Available at https:// www.who.int/csr/don/05-january-2020-pneumonia-of-unkown-cause-china/en/, last accessed on 5 February 2021.

WHO 2020b = Novel Coronavirus - China. Emergencies Preparedness, Response. World Health Organization (website), 12 January. Available at https://www.who.int/csr/ don/12-january-2020-novel-coronavirus-china/en/, last accessed on 5 February 2021.

WHO 2020c = Coronavirus Disease (COVID-19) Pandemic. World Health Organization (website). Available at https://www.who.int/emergencies/diseases/novelcoronavirus-2019, last accessed on 5 February 2021.

WHO 2020d = Novel Coronavirus (2019-nCoV): Situation Report 11. World Health Organization, 31 January. Available at https://www.who.int/docs/default-source/ coronaviruse/situation-reports/20200131-sitrep-11-ncov.pdf?sfvrsn=de7c0f7_4, last accessed on 5 February 2021.

\section{REFERENCES}

Ahmed, Wasim \& Vidal-Alaball, Josep \& Downing, Joseph \& López, Seguí Francesc 2020. COVID-19 and the 5G Conspiracy Theory: Social Network Analysis of Twitter Data. Journal of Medical Internet Research, Vol. 22, No. 5, e19458. DOI: $10.2196 / 19458$.

Blank, Trevor (ed.) 2009. Folklore and the Internet: Vernacular Expression in a Digital World. Logan, Utah: Utah State University Press.

Bostock, Bill 2020. People Seem to Think Corona Beer Is Related to the Deadly Wuhan Coronavirus Outbreak, as Searches for 'Corona Beer Virus' Are Trending. Business Insider, 29 January. Available at https://www.businessinsider.com/coronaviruscorona-beer-not-related-google-trends-2020-1, last accessed on 5 February 2021.

Brainard, Julii \& Hunter, Paul R. 2019. Misinformation Making a Disease Outbreak Worse: Outcomes Compared for Influenza, Monkeypox, and Norovirus. SIMULATION: Transactions of the Society for Modeling and Simulation International, Vol. 96, No. 4, pp. 365-374. http://dx.doi.org/10.1177/0037549719885021.

Burke, Jason 2019. Ebola Health Workers Killed and Injured by Rebel Attack in Congo. The Guardian, 28 November. Available at https://www.theguardian.com/globaldevelopment/2019/nov/28/ebola-health-workers-killed-and-injured-by-rebelattack-in-congo, last accessed on 5 February 2021.

Calisher, Charles \& Carroll, Dennis \& Colwell, Rita \& Corley, Ronald B. \& Daszak, Peter \& Drosten, Christian \& Enjuanes, Luis \& Farrar, Jeremy \& Field, Hume \& Golding, Josie \& Gorbalenya, Alexander \& Haagmans, Bart \& Hughes, James M. \& Karesh, William B. \& Keusch, Gerald T. \& Lam, Sai Kit \& Lubroth, Juan \& Mackenzie, John S. \& Madoff, Larry \& Mazet, Jonna \& Palese, Peter \& Perlman, Stanley \& Poon, Leo \& Roizman, Bernard \& Saif, Linda \& Subbarao, Kanta \& Turner, Mike 2020. Statement in Support of the Scientists, Public Health Professionals, and Medical Professionals of China Combatting COVID-19. The Lancet, 19 February. https://doi.org/10.1016/S0140-6736(20)30418-9. 
Denisova, Anastasia 2019. Internet Memes and Society: Social, Cultural, and Political Contexts. New York \& Oxon: Routledge.

Douglas, Karen M. \& Uscinski, Joseph E. \& Sutton, Robbie M. \& Cichocka, Aleksandra \& Nefes, Turkay \& Ang, Chee Siang \& Deravi, Farzin 2019. Understanding Conspiracy Theories. Advances in Political Psychology, Vol. 40, Suppl. 1, pp. 3-35. http://dx.doi.org/10.1111/pops.12568.

Event $201=$ Event 201. A Global Pandemic Exercise. Available at http://www. centerforhealthsecurity.org/event201, last accessed on 5 February 2021.

Goldstein, Diane E. 2004. Once upon a Virus: AIDS Legends and Vernacular Risk Perception. Logan, Utah: Utah State University Press.

Hiiemäe, Reet 1997. Eesti katkupärimus. [Estonian Plague Lore.] Monumenta Estoniae Antiquae II. Eesti Muistendid. Mütoloogilised haigused I. Tartu: Eesti Keele Instituut \& Eesti Kirjandusmuuseum.

Hiiemäe, Reet 1999. Katk ja aids - sarnaste fenomenide käsitlemine rahvapärimuses. [Plague and AIDS: Similar Phenomena in Folklore.] Kuuldust-nähtust: Tänapäeva folkloorist 4. Tartu: Eesti Kirjandusmuuseum, pp. 31-44. Available at http://www. folklore.ee/pubte/kuuldust/031Katkjaaids.html, last accessed on 5 February 2021.

Hiiemäe, Reet \& Kalda, Mare \& Kõiva, Mare \& Voolaid, Piret 2021. Vernacular Reactions to COVID-19 in Estonia: Crisis Folklore and Coping. Folklore: Electronic Journal of Folklore, Vol. 82, pp. 21-52. https://doi.org/10.7592/FEJF2021.82.estonia.

Keck, Frédéric \& Lachenal, Guillaume 2019. Simulations of Epidemics: Techniques of Global Health and Neo-Liberal Government. In: A.H. Kelly \& F. Keck \& Ch. Lynteris (eds.) The Anthropology of Epidemics. Oxon \& New York: Routledge, pp. 25-42.

Kharel, Gopi Chandra 2014. Ebola Is CIA-Created Demon? Conspiracy Theory Goes Viral as Meme Shows Disease Created by 'White People'. International Business Times, 19 September. Available at https://www.ibtimes.co.in/ebola-cia-createddemon-conspiracy-theory-goes-viral-meme-shows-disease-created-by-whitepeople-609490, last accessed on 5 February 2021.

Kõiva, Mare 2010. Patsiendinarratiivid internetis. [Patient Narratives on the Internet.] In: Piret Paal (ed.) Inimene, tervis ja haigused. Tänapäeva folkloorist 9. Tartu: EKM Teaduskirjastus, pp. 217-251.

Kõiva, Mare 2014. Inter-patient Narratives in the Internet. In: Mare Kõiva. Through the Ages II: Time, Space and Eternity. Sator 13. Tartu: ELM Scholarly Press, pp. 183-208. Available at http://www.folklore.ee/rl/pubte/ee/sator/sator13/, last accessed on 5 February 2021.

Laineste, Liisi \& Voolaid, Piret 2016. Laughing Across Borders: Intertextuality of Internet Memes. The European Journal of Humour Research, Vol. 4, No. 4, pp. 26-49. http://dx.doi.org/10.7592/EJHR2016.4.4.laineste.

Lee, Jon D. 2014. An Epidemic of Rumors: How Stories Shape Our Perceptions of Disease. Boulder, Colorado: Utah State University Press.

McNeill, Lynne S. 2018. "My friend posted it and that's good enough for me!": Source Perception in Online Information Sharing. Journal of American Folklore, Vol. 131, No. 522, pp. 493-499. DOI: 10.5406/jamerfolk.131.522.0493.

Michelmore, Karen \& Parish, Rebecca \& O'Connor, Kendall 2020. Christmas Island Locals Surprised, Split Over Quarantine of Australians from Coronavirus Epicentre. ABC News, 29 January. Available at https://www.abc.net.au/news/2020-01-29/ christmas-island-locals-on-quarantine-for-coronavirus/11910326, last accessed on 5 February 2021. 
Paganini, Pierluigi 2020. New Cyber Attack Campaign Leverages the COVID-19 Infodemic. Security Affairs, 26 February. Available at https://securityaffairs. co/wordpress/98484/malware/covid-19-hacking-campaign.htm, last accessed on 5 February 2021.

Shifman, Limor 2014. Memes in Digital Culture. Cambridge, MA \& London, England: The MIT Press.

Shifman, Limor \& Levy, Hadar \& Thelwall, Mike 2014. Internet Jokes: The Secret Agents of Globalization? Journal of Computer-Mediated Communication, Vol. 19, No. 4, pp. 727-743. http://dx.doi.org/10.1111/jcc4.12082.

Shimizu, Kazuki 2020. 2019-nCOV, Fake News, and Racism. The Lancet, Vol. 395, No. 10225, pp. 685-686. https://doi.org/10.1016/S0140-6736(20)30357-3.

Tavast, Johannes 2020 [1931]. Jüri kihelkond. Ajaloolist traditsiooni kogunud Jürist 1931. a. suvel Johannes Tavast. [Jüri Parish. Historical Tradition Collected from Jüri Parish by Johannes Tavast in Summer 1931.] EKLA F. 199, M 54. Tartu: EKM Teaduskirjastus. Available at http://folklore.ee/pubte/ajaloolist/jyr, last accessed on 5 February 2021.

The Guardian 2020 = Britons Returning from China to Be 'Safely Isolated' for 14 Days, Says Hancock - As It Happened. The Guardian, 29 January. Available at https:// www.theguardian.com/world/live/2020/jan/29/coronavirus-live-updates-chinawuhan-death-toll-cases-symptoms-treatment-evacuation-us-japanese-citizenslatest-news?page=with:block-5e317d8b8f08e133247390a5, last accessed on 4 February 2021.

The Local 2020 = China Demands Apology over Danish Newspaper's Cartoon Flag 'Insult'. The Local, 28 January. Available at https://www.thelocal.dk/20200128/ china-demands-apology-over-danish-newspapers-cartoon-flag-insult, last accessed on 5 February 2021.

Voolaid, Piret 2014. Olümpiavõitja kui rahvuskangelane: folkloristlik vaade ühele dopingujuhtumile. [Olympic Champion as a National Hero: Folkloristic View of One Doping Case.] Mäetagused, Vol. 58, pp. 53-84. http://dx.doi.org/10.7592/MT2014.58.voolaid.

Xiong, Yong \& Gan, Nectar 2020. This Chinese Doctor Tried to Save Lives, But Was Silenced. Now He Has Coronavirus. CNN, 4 February. Available at https://edition. cnn.com/2020/02/03/asia/coronavirus-doctor-whistle-blower-intl-hnk/index.html, last accessed on 5 February 2021.

White, Alexandre I. R. 2020. Historical Linkages: Epidemic Threat, Economic Risk, and Xenophobia. The Lancet, Vol. 395, No. 10232, pp. 1250-1251. http://dx.doi. org/10.1016/S0140-6736(20)30737-6.

Maris Kuperjanov works as an archivist-referent at the Department of Folkloristics of the Estonian Literary Museum, administrating the department's research archive. She formerly worked at the Department of Folkloristics as an assistant and editor, and at the Estonian Literary Museum Scholarly Press, performing pre-press activities for folkloristic publications, among others for the journals Folklore: Electronic Journal of Folklore and Mäetagused. She has also worked in the field of clinical research.

maris.kuperjanov@folklore.ee 